\title{
Resistance of winter wheat cultivars to yellow rust caused by Puccinia striiformis f. sp. tritici
}

\section{Odporność odmian pszenicy ozimej na rdzę żółtą powodowaną przez Puccinia striiformis f. sp. tritici}

\author{
Magdalena Radecka-Janusik, Paweł Cz. Czembor*, Grzegorz Czajowski
}

\begin{abstract}
Summary
An isolate of Puccinia striiformis f. sp. tritici "Warrior" race (avirulent to Yr5 and Yr15 resistance genes) was used in the study to test resistance among winter wheat cultivars. The examined plant material consisted of eighty-three winter wheat cultivars and lines with resistance genes to yellow rust Yr5 and Yr15. The pathology tests were conducted on the seedlings under controlled conditions. Plant symptoms caused by infection were evaluated 12-14 days after inoculation using 0-9 scale. Six cultivars were found to be resistant to Pst isolate (score 0-4), and only the cultivar Belenus and lines with genes Yr5 and Yr15 were completely immune (score 0). Nine cultivars revealed intermediate resistance (score 5-6) and 67 were susceptible (score 7-9). Additional experiments were carried out to identify genes $Y r 5$ and $Y r 15$ among tested wheat cultivars by using molecular markers. The results demonstrated that phenotypic and molecular results were consistent only for Belenus cultivar, which indicated the presence of Yr15 in this cultivar.
\end{abstract}

Key words: molecular markers; Puccinia striiformis f. sp. tritici; resistance genes; Warrior race; wheat

\section{Streszczenie}

W pracy badano odporność odmian pszenicy ozimej na izolat Puccinia striiformis f. sp. tritici typu "Warrior" (awirulentny w stosunku do genów Yr5 i Yr15). Materiał roślinny stanowiły 83 odmiany pszenicy ozimej oraz linie posiadające geny odporności na rdzę żółtą Yr5 i Yr15. Testy przeprowadzono na siewkach w komorze klimatycznej. Po 12-14 dniach od inokulacji określono typ reakcji rośliny według skali 0-9. Wyróżniono 6 odmian odpornych (zakres oceny 0-4) na testowany izolat Pst, przy czym tylko dla odmiany Belenus oraz linii zawierających geny Yr5 i Yr15 zanotowano ocenę 0 (brak widocznych objawów chorobowych). W przypadku 9 odmian zaobserwowano odporność pośrednią (ocena 5-6), natomiast 67 odmian było podatnych (ocena 7-9). Podjęto również próbę określenia występowania genów odporności Yr5 i Yr15 wśród badanych odmian pszenicy przy użyciu markerów molekularnych. Tylko w przypadku odmiany Belenus uzyskano zbieżność wyników fenotypowych i molekularnych, co wskazuje na obecność genu Yr15 w tej odmianie.

Słowa kluczowe: markery molekularne; Puccinia striiformis f. sp. tritici; geny odporności; rasa Warrior; pszenica

Instytut Hodowli i Aklimatyzacji Roślin - Państwowy Instytut Badawczy

Radzików, 05-870 Błonie

*corresponding author: p.czembor@ihar.edu.pl 


\section{Wstęp / Introduction}

Rdza żółta zbóż i traw jest powodowana przez grzyba Puccinia striiformis, a jego forma specjalna tritici (Pst), która poraża pszenicę może powodować w sprzyjających warunkach duże straty w plonie (Morgounov i wsp. 2012; Chen i wsp. 2014). Populacja tego grzyba w rejonie Azji Środkowej ma charakter populacji rekombinacyjnej, natomiast w Europie, Ameryce Północnej i Australii jest populacją klonalną (Hovmøller i wsp. 2016). Urediniospory grzyba mogą być przenoszone $\mathrm{z}$ wiatrem tysiące kilometrów od pierwotnego źródła infekcji, co umożliwia pojawienie się nowych wariantów wirulencji patogena $\mathrm{w}$ różnych rejonach świata, zwiększając w ten sposób zmienność genetyczną lokalnych populacji i ich zdolności adaptacyjne do warunków środowiska (w tym odporności gospodarza).

Miarą zagrożenia plantacji zbóż ze strony patogena może być częstość i szybkość rozprzestrzeniania się nowych ras grzyba. W roku $2011 \mathrm{w}$ Europie na pszenicy wykryto nowe rasy nazwane „Warrior” i „Kranich”, które w odróżnieniu od dotychczas notowanych, spowodowały wystąpienie choroby w nienotowanym dotąd nasileniu w wielu krajach Europy (Hovmøller i wsp. 2016).

Jak dotąd opisano 76 genów odporności $(Y r)$ na rdzę żółtą zbóż i traw (KOMUGI 2016). Zazwyczaj wyróżnia się dwie klasy genów: rasowo-specyficzne (R) i geny odporności rośliny dorosłej (APR - Adult Plant Resistance) (Chen 2013). Odporność typu R (genów głównych) warunkuje odporność całkowitą i efektywną we wszystkich stadiach wzrostu rośliny, która manifestuje się reakcją nadwrażliwości. Geny APR warunkują zazwyczaj odporność rasowo-niespecyficzną, obserwowaną tylko dla rośliny dorosłej i w odróżnieniu od genów $\mathrm{R}$, zwykle jest odpornością częściową (spowalnianie objawów chorobowych). Wśród genów głównych, Yr5 i Yr15 należą do najbardziej efektywnych, ponieważ jak dotąd w Europie i w większości innych rejonów świata nie zanotowano wirulentnych izolatów Pst względem tych genów (Sharma-Poudyal i wsp. 2013). W literaturze jest szereg przykładów typowania genów odporności Yr5 i Yr15 w materiałach hodowlanych i odmianach pszenicy przy pomocy markerów molekularnych (Murphy i wsp. 2009; Yaniv i wsp. 2015; Li i wsp. 2016).

Wykorzystanie odporności roślin na porażenie przez patogeny w ograniczaniu strat w plonie należy do tanich i bezpiecznych metod dla środowiska. Z tego względu zajmuje ona ważne miejsce w programach hodowlanych (Johnson 1992) i jest wykorzystywana w programach integrowanej ochrony roślin (Tratwal i Gacek 2013). $\mathrm{W}$ związku z tym, konieczne jest stałe gromadzenie wiedzy o odporności roślin i zagrożeniach związanych ze zmianami zdolności chorobotwórczych patogena.

Celem pracy było zbadanie odporności odmian pszenicy ozimej w stadium siewki na rasę „Warrior” grzyba P. striiformis f. sp. tritici oraz podjęcie próby oznaczenia występowania u badanych odmian genów odporności Yr5 i Yr15 przy pomocy sprzężonych z nimi markerów molekularnych.

\section{Materiały i metody / Materials and methods}

W badaniach nad reakcją roślin na porażenie przez Pst wykorzystano 83 odmiany pszenicy ozimej pochodzące z krajowej listy opisowej odmian COBORU (2013). Dodatkowo jako wzorcowe zostały użyte odmiany/linie pszenicy należące do zestawu różnicującego na rdzę żółtą: Avocet S - wzorzec podatny na większość ras Pst, linia bliskoizogeniczna Avocet S/Yr5 (gen odporności Yr5) oraz odmiana Cortez posiadająca gen Yr15. Łącznie badano 86 obiektów. Doświadczenia fitopatologiczne przeprowadzono przy użyciu izolatu Pst15WT-02-131 (wyprowadzonego $\mathrm{z}$ pojedynczego uredinium) pochodzącego $\mathrm{z}$ własnej kolekcji. Jest to izolat typu Warrior, czyli wirulentny względem genów odporności $Y r:$ 1, 2, 3, 4, 6, 7, 9, 17, 25, 32, $\mathrm{Sp}$, Amb. W badanym zestawie różnicującym (Hovmøller 2007), posiadającym znane geny odporności wymieniony izolat był awirulentny względem genów $Y r$ : 5, 15, 24, 27.

Test przeprowadzono w komorze klimatycznej w warunkach kontrolowanych światła i temperatury. Nasiona (3-5) każdego z 86 badanych obiektów wysiano do osobnego oczka palety ogrodniczej o wymiarach $36 \mathrm{~cm} \times 56 \mathrm{~cm}$ (paleta zawiera 104 oczka, każde oczko o wymiarach $3,5 \times 3,5 \mathrm{~cm})$. Na potrzeby testu izolat namnażano na siewkach podatnej odmiany pszenicy Michigan Amber, z których po 12-14 dniach od inokulacji zebrano świeże urediniospory. Następnie odważono $100 \mathrm{mg}$ zarodników, z których sporządzono zawiesinę wodną o objętości $20 \mathrm{ml}$ uzupełnioną kroplą surfaktantu Tween 20 (Sigma, Polska). Uzyskana zawiesina zarodników została użyta natychmiast po sporządzeniu do inokulacji roślin w stadium drugiego liścia (ręczny mikro opryskiwacz), które pozostawiono do następnego dnia w warunkach całkowitej ciemności, w temperaturze $8^{\circ} \mathrm{C}$ i wilgotności względnej bliskiej $100 \%$. Następnie siewki utrzymywano w warunkach 16 godzin światła $/ 17^{\circ} \mathrm{C}$ oraz 8 godzin ciemności $/ 12^{\circ} \mathrm{C}$. Po 12-14 dniach od inokulacji określono typ reakcji rośliny według skali 0-9 (McNeal 1971), gdzie 0-4 oceniano jako odporny, 5-6 - pośredni, natomiast 7-9 - podatny.

Na potrzeby analiz molekularnych wyizolowano DNA przy użyciu DNeasy Plant Mini Kit (QIAGEN GmbH, 140724 Hilden, Niemcy). Do analizy występowania genów Yr5 i Yr15 w odmianach pszenicy wykorzystano markery molekularne wyszczególnione w tabeli 1. Dla markerów: S23M41, STS7/8, STS9/10 i Gwm273 przeprowadzono reakcję PCR (polymerase chain reaction) w objętości $8 \mu \mathrm{l}$, która zawierała następujące komponenty: 60 ng DNA, 1U Taq polimerazy (Thermo Fisher Scientific), $1 \times$ PCR bufor $\mathrm{z}$ domieszką (NH4) $\mathrm{SO}_{4}$ (Thermo Fisher Scientific), $2,5 \mathrm{mM} \mathrm{MgCl}_{2}$ (Thermo Fisher Scientific), $200 \mu \mathrm{M}$ każdego $\mathrm{z}$ deoksynukleotydów (Thermo Fisher Scientific) oraz po $0,5 \mu \mathrm{M}$ każdego z pary starterów (przy czym jeden z pary starterów był znakowany barwnikiem fluorescencyjnym: 6-FAM, HEX lub TET). Amplifikacja prowadzona była według programu: $94^{\circ} \mathrm{C} / 3 \mathrm{~min}$.; $\left(94^{\circ} \mathrm{C} / 30 \mathrm{~s}\right.$, temperatura przyłączania starterów do DNA (Ta) zależna od markera $/ 30 \mathrm{~s}, 72^{\circ} \mathrm{C} / 1 \mathrm{~min}$.) $\times 40 \mathrm{cykli} ; 72^{\circ} \mathrm{C} / 10 \mathrm{~min}$. i na końcu $4^{\circ} \mathrm{C} /$ do czasu zakończenia programu. Temperatura Ta dla: S23M41, STS7/8, STS9/10 i Gwm273 wynosiła odpowiednio: $58,45,45$ i $55^{\circ} \mathrm{C}$. 
W przypadku markerów Barc167, Gwm413 i Wmc128 zastosowano system amplifikacji PCR typu „M13” (Rampling i wsp. 2001). W odróżnieniu od wcześniej opisanego układu reakcji, dodany jest starter M13 w stężeniu $0,5 \mu \mathrm{M}$ (5'-CACGACGTTGTAAAACGAC-3'), który jest znakowany na końcu 5' barwnikiem fluorescencyjnym (nie są znakowane pozostałe startery „forward” i „reverse”). Ponadto, starter „forward” na końcu 5' ma dołączoną sekwencję M13 (nieznakowaną), który występuje w stężeniu $0,1 \mu \mathrm{M}$, a starter „reverse” $-0,5 \mu \mathrm{M}$. Amplifikacja prowadzona była według programu: $94^{\circ} \mathrm{C} / 3$ min.; $\left(94^{\circ} \mathrm{C} / 30 \mathrm{~s}, 65 \downarrow 51^{\circ} \mathrm{C} / 30 \mathrm{~s}, 72^{\circ} \mathrm{C} / \mathrm{min}\right.$.); $\left(94^{\circ} \mathrm{C} / 30 \mathrm{~s}\right.$, $50^{\circ} \mathrm{C} / 30 \mathrm{~s}, 72^{\circ} \mathrm{C} / 1 \mathrm{~min}$.) $\times 30 \mathrm{cykli} ; 72^{\circ} \mathrm{C} / 10 \mathrm{~min}$. i na końcu $4{ }^{\circ} \mathrm{C} /$ do czasu zakończenia programu, przy czym podany $\mathrm{w}$ formule symbol $\downarrow$ oznacza obniżenie temperatury przyłączania starterów z każdym cyklem o $1^{\circ} \mathrm{C}$ we wskazanym przedziale temperatur (Rampling i wsp. 2001).

Do rozdziału i detekcji otrzymanych produktów PCR wykorzystano analizator DNA ABI377XL (Applied Biosystems) wspomagany oprogramowaniem GeneScan 3.1 (Applied Biosystems), stosując 4,5\% denaturujący żel poliakrylamidowy (Long Ranger, Cambrex Bio Science). Do nanoszenia mieszaniny poreakcyjnej na żel poliakrylamidowy zastosowano grzebienie membranowe (100 zębów) zgodnie $\mathrm{z}$ zaleceniem producenta (Web Scientific Ltd., Wielka Brytania).

\section{Wyniki i dyskusja / Results and discussion}

Badania nad chorobotwórczością izolatów Pst są prowadzone w Europie od kilkudziesięciu lat (Woźniak-Strzembicka 2003). Przeprowadzone w pracy testy fenotypowe i analizy molekularne umożliwiły podjęcie próby identyfikacji genów odporności na rdzę żółtą w odmianach pszenicy ozimej zarejestrowanych w Polsce. Testowany izolat Pst15WT-02-131 był awirulentny zarówno w stosunku do genu Yr5, jak i Yr15. W wyniku inokulacji 83 odmian pochodzących z krajowej listy opisowej odmian COBORU (2013) wyróżniono 6 odmian wykazujących odporność (ocena w zakresie 0-4) na badany izolat Pst: Belenus, Estivus, Fakir, KWS Dacanto, KWS Livius oraz Nutka. Najniższy stopień porażenia zaobserwowano w przypadku odmiany Belenus (typ reakcji fenotypowej - 0). Pośredni typ reakcji zaobserwowano w przypadku 9 odmian (ocena w zakresie 5-6). Z kolei w stosunku do 67 odmian badany izolat wykazywał wysoki poziom wirulencji (typ reakcji 7-9). Jedna z odmian, Ostka Strzelecka charakteryzowała się mieszanym typem reakcji, który świadczył prawdopodobnie o zamieszaniu nasion różnych genotypów. Szczegółowe wyniki oceny fenotypowej przedstawia tabela 2.

Na podstawie analiz molekularnych odmian pszenicy ozimej określono występowanie następujących markerów blisko sprzężonych z genami Yr: Yr5-Barc167, Yr5-S23M41, Yr5-STS7/8, Yr5-STS9/10, Yr15-Gwm413, Yr15-Wmc128 i Yr15-Gwm273 (tab. 1). Niestety, dla markerów S23M41, STS7/8 i STS9/10 sprzężonych z Yr5 nie zanotowano polimorfizmu DNA (różnicy długości amplifikowanych fragmentów DNA lub obecność/brak produktu PCR) pomiędzy obiektami kontrolnymi, tj. linią
Avocet S/Yr5 i odmianą Cortez (Yr15) (dane nieprzedstawione). W związku z tym nie było możliwe rozróżnienie badanych genów odporności przy użyciu wspomnianych markerów i zrezygnowano z ich dalszego badania. Spośród markerów sprzężonych $\mathrm{z}$ genem $\operatorname{Yr} 5$, tylko Barc167 wykazywał obecność diagnostycznego produktu PCR (275 pz), który wykryto w odmianach: Artist, Estivus, Fakir, Forum, Praktik i Wydma (tab. 2). Wykazano zbieżność analiz molekularnych i odpornościową reakcję fenotypową dla odmian Estivus i Fakir, jednak ocena odpowiednio 3 i 4, znacznie odbiega od reakcji fenotypowej typu 0 występującej u linii kontrolnej Avocet S/Yr5. W związku z tym, jest wysoce prawdopodobne, że gen $\operatorname{Yr} 5$ nie występuje wśród badanych odmian pszenicy ozimej. Natomiast jest możliwe, że za reakcję odporności odmian: Artist, Estivus, Fakir, Forum, Praktik i Wydma jest odpowiedzialny inny gen lub kilka genów względem których użyty w testach izolat Pst jest awirulentny, np. Yr24 i Yr27. Li i wsp. (2016) również użyli markera Barc167 i dodatkowo Barc349 do typowania obecności genu Yr5 w 115 chińskich odmianach/liniach pszenicy, co zaowocowało wykryciem specyficznego produktu PCR dla obydwu markerów w 5 genotypach: Pingan 8, An 0817, Kenong 1006, Wanke 06290 i Zhongmai 349. Autorzy postulują występowanie Yr5 w Kenong 1006 i Wanke 06290 mimo braku zbieżności oceny fenotypowej (reakcja odporności) dla przynajmniej jednego z użytych izolatów Pst CYR32 i V26 z kontrolnymi liniami Avocet S/Yr5 i Triticum spelta album (dawcy Yr5). W przypadku Pingan 8 autorzy dopuszczają możliwość pochodzenia odporności od jednej $\mathrm{Z}$ form rodzicielskich Zhou $8425 \mathrm{~B}$ posiadającej gen YrZh84. Niejednoznaczność cytowanych wyników (Li i wsp. 2016) oraz wątpliwości przy analizie własnych wskazują na zawodność opisywanych markerów SSR, w tym również Barc167 jako wiarygodnego narzędzia typowania genu Yr5. Znajduje to swoje uzasadnienie w wynikach pracy Murphy i wsp. (2009), którzy analizowali markery molekularne sprzężone z $\operatorname{Yr} 5 \mathrm{w} 10$ genotypach o różnym pochodzeniu i obecności genu Yr5 w kombinacji z genami: $\operatorname{Yr} 15$, GPC, Lr47, 2NS i St10. W pracy wykorzystano markery: Barc167, Barc349, Wmc175, STS7/8 i STS7/8 CAPS (produkt PCR dodatkowo cięty restryktazą DpnII), niestety żaden $\mathrm{z}$ nich nie był w pełni diagnostyczny. Może to wynikać najczęściej z utraty sprzężenia marker-gen na drodze rekombinacji mejotycznej $\mathrm{w}$ trakcie procesu hodowlanego mającego na celu wprowadzenie $\mathrm{z}$ materiałów źródłowych pożądanego genu do innych genotypów (Collard i Mackill 2008).

Gen Yr15 identyfikowano na podstawie markerów mikrosatelitarnych (SSR) Gwm413, Wmc128 i Gwm273, które wykazywały polimorfizm DNA i obecność diagnostycznego produktu PCR (tab. 1). Tylko w przypadku odmiany wzorcowej - Cortez posiadającej gen $\operatorname{Yr} 15$ występowały specyficzne (diagnostyczne) produkty PCR dla wszystkich trzech użytych markerów SSR (tab. 2). U odmian: Bamberka, Praktik i Türkis zidentyfikowano tylko marker Gwm273, ale przy ich jednoczesnej reakcji podatności (ocena 7-8) należy wykluczyć obecność Yr15 w tych odmianach. Prawdopodobnie zaistniała sytuacja wynika z utraty sprzężenia Gwm273 z genem $\operatorname{Yr} 15$, ponieważ wspomniany marker według różnych autorów jest 
Tabela 1. Markery molekularne sprzężone z genami odporności na rdzę żółtą (Puccinia striiformis f. sp. tritici)

Table 1. Molecular markers linked to resistance genes to yellow rust (Puccinia striiformis f. sp. tritici)

\begin{tabular}{c|c|c|c}
\hline \multirow{3}{*}{$\begin{array}{c}\text { Geny } Y r \\
\text { Yr genes }\end{array}$} & $\begin{array}{c}\text { Marker molekularny } \\
\text { (odległość markera od genu w cM) } \\
\text { Molecular marker } \\
\text { (marker distance from the gene in cM) }\end{array}$ & $\begin{array}{c}\text { Wielkość produktu PCR } \\
\text { (liczba par zasad, pz) } \\
\text { PCR product size } \\
\text { (base pair numer, bp) }\end{array}$ & $\begin{array}{c}\text { Publikacja źródłowa } \\
\text { Reference }\end{array}$ \\
\hline \multirow{5}{*}{ Yr5 } & Barc167 (2,6) & 275 & Murphy i wsp. 2009 \\
\cline { 2 - 4 } & S23M41(0,7) & 275 & Smith i wsp. 2007 \\
\cline { 2 - 4 } & STS7/8 $(0,3)$ & 478 & MASWheat 2016 \\
\hline \multirow{3}{*}{ Yr15 } & STS9/10 (0,7) & 439 & Murphy i wsp. 2009 \\
\cline { 2 - 4 } & Gwm413 (0,0) & 120 & Murphy i wsp. 2009 \\
\cline { 2 - 4 } & Wmc128 (0,4) & 235 & Murphy i wsp. 2009 \\
\hline
\end{tabular}

i wsp. - et al.

Tabela 2. Występowanie markerów molekularnych sprzężonych z genami odporności na rdzę żółtą Yr5 i Yr15 w odmianach pszenicy ozimej oraz ocena reakcji fenotypowej odmian na porażenie izolatem Puccinia striiformis f. sp. tritici Pst15WT-02-131

Table 2. Molecular markers linked to yellow rust resistance genes $\operatorname{Yr} 5$ and $\operatorname{Yr} 15$ in winter wheat cultivars and phenotypic reaction of wheat cultivars to Puccinia striiformis f. sp. tritici isolate Pst15WT-02-131

\begin{tabular}{|c|c|c|c|c|c|c|}
\hline \multirow{3}{*}{$\begin{array}{l}\text { Odmiana } \\
\text { Cultivar }\end{array}$} & \multicolumn{4}{|c|}{ Gen/Marker - Gene/Marker } & \multirow{3}{*}{$\begin{array}{l}\text { Odmiana } \\
\text { Cultivar }\end{array}$} & \multirow{3}{*}{$\begin{array}{l}\text { Ocena fenotypowa* } \\
\text { Phenotypic assesmen }\end{array}$} \\
\hline & \multirow{2}{*}{$\begin{array}{c}\text { Yr5 } \\
\text { Barc167 }\end{array}$} & \multicolumn{3}{|c|}{ Yr15 } & & \\
\hline & & Gwm413 & Wmc128 & Gwm273 & & \\
\hline 1 & 2 & 3 & 4 & 5 & 6 & 7 \\
\hline Avocet S & - & - & - & - & Avocet S & 9 \\
\hline Avocet S/Yr5 & + & - & - & - & Avocet S/Yr5 & 0 \\
\hline Cortez (Yr15) & - & + & + & + & Cortez (Yr15) & 0 \\
\hline Akteur & - & - & - & - & Akteur & 7 \\
\hline Alcazar & - & - & - & - & Alcazar & 6 \\
\hline Arkadia & - & - & - & - & Arkadia & 7 \\
\hline Arktis & - & - & - & - & Arktis & 5 \\
\hline Artist & + & - & - & - & Artist & 7 \\
\hline Askalon & - & - & - & - & Askalon & 5 \\
\hline Astoria & - & - & - & - & Astoria & 7 \\
\hline Bagou & - & - & - & - & Bagou & 7 \\
\hline Baletka & - & - & - & - & Baletka & 8 \\
\hline Bamberka & - & - & - & + & Bamberka & 8 \\
\hline Banderola & - & - & - & - & Banderola & 8 \\
\hline Batuta & - & - & - & - & Batuta & 7 \\
\hline Belenus & - & + & - & - & Belenus & 0 \\
\hline Bockris & - & - & - & - & Bockris & 7 \\
\hline Bogatka & - & - & - & - & Bogatka & 7 \\
\hline Boomer & - & - & - & - & Boomer & 7 \\
\hline Bystra & - & - & - & - & Bystra & 8 \\
\hline Dorota & - & - & - & - & Dorota & 5 \\
\hline Elipsa & - & - & - & - & Elipsa & 7 \\
\hline Estivus & + & - & - & - & Estivus & 3 \\
\hline Fakir & + & - & - & - & Fakir & 4 \\
\hline Fidelius & - & - & - & - & Fidelius & 7 \\
\hline Figura & - & - & - & - & Figura & 7 \\
\hline
\end{tabular}




\begin{tabular}{|c|c|c|c|c|c|c|}
\hline 1 & 2 & 3 & 4 & 5 & 6 & 7 \\
\hline Forkida & - & - & - & - & Forkida & 7 \\
\hline Forum & + & - & - & - & Forum & 8 \\
\hline Fregata & - & - & - & - & Fregata & 8 \\
\hline Garantus & - & - & - & - & Garantus & 7 \\
\hline Henrik & - & - & - & - & Henrik & 7 \\
\hline Jantarka & - & - & - & - & Jantarka & 7 \\
\hline Jenga & - & - & - & - & Jenga & 7 \\
\hline Kampana & - & - & - & - & Kampana & 6 \\
\hline Kepler & - & - & - & - & Kepler & 7 \\
\hline Kobiera & - & - & - & - & Kobiera & 5 \\
\hline Kohelia & - & - & - & - & Kohelia & 7 \\
\hline Kranich & - & - & - & - & Kranich & 7 \\
\hline Kredo & - & - & - & - & Kredo & 7 \\
\hline Kris & - & - & - & - & Kris & 7 \\
\hline KWS Dacanto & - & - & - & - & KWS Dacanto & 2 \\
\hline KWS Livius & - & - & - & - & KWS Livius & 4 \\
\hline KWS Magic & - & - & - & - & KWS Magic & 7 \\
\hline KWS Ozon & - & - & - & - & KWS Ozon & 7 \\
\hline Lavantus & - & - & - & - & Lavantus & 7 \\
\hline Legenda & - & - & - & - & Legenda & 7 \\
\hline Linus & - & - & - & - & Linus & 7 \\
\hline Look & - & - & - & - & Look & 7 \\
\hline Ludwig & - & - & - & - & Ludwig & 7 \\
\hline Markiza & - & - & - & - & Markiza & 7 \\
\hline Meister & - & - & - & - & Meister & 6 \\
\hline Meteor & - & - & - & - & Meteor & 7 \\
\hline Mewa & - & - & - & - & Mewa & 7 \\
\hline Mikula & - & - & - & - & Mikula & 7 \\
\hline Mulan & - & - & - & - & Mulan & 7 \\
\hline Muszelka & - & - & - & - & Muszelka & 7 \\
\hline Muza & - & - & - & - & Muza & 8 \\
\hline Naridana & - & - & - & - & Naridana & 7 \\
\hline Natula & - & - & - & - & Natula & 7 \\
\hline Nutka & - & - & - & - & Nutka & 3 \\
\hline Olivin & - & - & - & - & Olivin & 7 \\
\hline Operetka & - & - & - & - & Operetka & 7 \\
\hline Ostka Strzelecka & - & - & - & - & Ostka Strzelecka & $4 \mathrm{i} 7$ \\
\hline Ostroga & - & - & - & - & Ostroga & 7 \\
\hline Oxal & - & - & - & - & Oxal & 7 \\
\hline Patras & - & - & - & - & Patras & 8 \\
\hline Pengar & - & - & - & - & Pengar & 7 \\
\hline Platin & - & - & - & - & Platin & 7 \\
\hline Praktik & + & - & - & + & Praktik & 7 \\
\hline Rapsodia & - & - & - & - & Rapsodia & 6 \\
\hline Rywalka & - & - & - & - & Rywalka & 7 \\
\hline
\end{tabular}




\begin{tabular}{l|l|l|l|l|l|l}
\hline \multicolumn{1}{c|}{1} & 2 & 3 & 4 & 5 & \multicolumn{1}{|c}{6} & 7 \\
\hline Sailor & - & - & - & - & Sailor & 7 \\
\hline Satyna & - & - & - & - & Satyna & 8 \\
\hline Skagen & - & - & - & - & Skagen & 7 \\
\hline Smaragd & - & - & - & - & Smaragd & 7 \\
\hline Smuga & - & - & - & - & Smuga & 7 \\
\hline Speedway & - & - & - & - & Speedway & 7 \\
\hline Sukces & - & - & - & - & Sukces & 7 \\
\hline Tonacja & - & - & - & - & Tonacja & 6 \\
\hline Torrild & - & - & - & - & Torrild & 8 \\
\hline Tulecka & - & - & - & - & Tulecka & 7 \\
\hline Türkis & - & - & - & + & Türkis & 7 \\
\hline Turnia & - & - & - & - & Wydma & 7 \\
\hline Wydma & - & - & - & - & Zawisza & 7 \\
\hline Zawisza & - & - & - & Zyta & 7 \\
\hline
\end{tabular}

*skala: 0-4 - odporny, 5-6- pośredni, 7-8 - podatny - scale: 0-4 - resistant, 5-6 - intermediate, 7-8 - susceptible

+ obecność diagnostycznego produktu PCR markera sprzężonego z genem odporności - presence of PCR diagnostic product for marker linked to the resistance gene

- brak diagnostycznego produktu PCR markera sprzężonego z genem odporności - absence of PCR diagnostic product for marker linked to the resistance gene

oddalony od genu odporności o 0,4-4,6 cM (Murphy i wsp. 2009; Yaniv i wsp. 2015). Natomiast najbardziej sprzężony z genem Yr15 marker Gwm413 (Murphy i wsp. 2009) wykryto tylko u odmiany Belenus, która jednocześnie wykazywała najwyższy stopień odporności (ocena 0 ) zbieżny $\mathrm{z}$ oceną fenotypową odmianą Cortez. W związku z tym należy wnioskować, że odmiana Belenus posiada gen $\operatorname{Yr} 15$. Dodatkowo za tym przypuszczeniem przemawia rodowód odmiany Belenus, w którym występuje odmiana Cortez posiadająca gen Yr15 (Hovmøller 2007; Sortinfo 2016). Wiarygodność markera Gwm413 w identyfikacji genu Yr15 została potwierdzona przez innych autorów (Murphy i wsp. 2009; Yaniv i wsp. 2015), którzy badali możliwość wykrywania tego genu w różnym tle genetycznym.

Przedstawione wyniki w niniejszej pracy są wysoce niepokojące, ponieważ zdecydowana większość odmian pszenicy ozimej wymienionych w krajowej liście opisowej odmian COBORU (2013) była podatna na zakażenie izolatem Pst rasy „Warrior”, która w latach 2014 i 2015 dominowała $w$ Polsce i wielu innych krajach Europy (GRRC 2016; Hovmøller i wsp. 2016). Dlatego, wydaje się wysoce wskazane podjęcie natychmiastowych kroków zmierzających do wprowadzenia obecnie efektywnych genów odporności, wśród nich Yr15, który nadaje wyjąt- kowo szerokie spektrum odporności względem dużej kolekcji izolatów Pst na całym świecie (Yaniv i wsp. 2015). Odmiana pszenicy ozimej Belenus, w której z dużym prawdopodobieństwem występuje gen Yr15 może być komponentem rodzicielskim wykorzystanym w obecnych programach hodowlanych w Polsce.

\section{Wnioski / Conclusions}

1. Tylko niewielka liczba odmian z krajowej listy opisowej odmian COBORU wykazuje reakcję odporności w stadium siewki na zakażenie izolatem Pst typu „Warrior”, który obecnie dominuje w Europie. Jedynie dla odmiany Belenus zaobserwowano całkowitą reakcję immunii.

2. Tylko marker molekularny Gwm413 był przydatny w genotypowaniu genu odporności Yr15, co pozwoliło na jego identyfikację w odmianie pszenicy ozimej Belenus.

3. Żaden $\mathrm{z}$ markerów molekularnych opisywanych w literaturze nie pozwolił na jednoznaczne genotypowanie wśród badanych odmian pszenicy ozimej genu odporności Yr5.

\section{Literatura / References}

Chen W., Wellings C., Chen X., Kang Z., Liu T. 2014. Wheat stripe (yellow) rust caused by Puccinia striiformis f. sp. tritici. Molecular Plant Pathology 15 (5): 433-446. DOI: 10.1111/mpp.12116.

Chen X. 2013. Review article: high-temperature adult-plant resistance, key for sustainable control of stripe rust. American Journal of Plant Sciences 4 (3): 608-627. DOI: 10.4236/ajps.2013.43080.

COBORU 2013. http://www.coboru.pl/Polska/Rejestr/gat_w_rej.aspx [dostęp: 10.01.2013].

Collard B.C.Y., Mackill D.J. 2008. Marker-assisted selection: an approach for precision plant breeding in the twenty-first century. Philosophical Transactions of the Royal Society B Biological Sciences 363 (1491): 557-572. DOI: 10.1098/rstb.2007.2170. 
GRRC - Global Rust Reference Center 2016. http://wheatrust.org/ [Accessed: 15.11.2016].

Hovmøller M.S. 2007. Sources of seedling and adult plant resistance to Puccinia striiformis f.sp. tritici in European wheats. Plant Breeding 126 (3): 225-233. DOI: 10.1111/j.1439-0523.2007.01369.x.

Hovmøller M.S., Walter S., Bayles R., Hubbard A., Flath K., Sommerfeldt N., Leconte M., Czembor P., Rodriguez-Algaba J., Thach T., Hansen J.G., Lassen P., Justesen A.F., Ali S., de Vallavieille-Pope C. 2016. Replacement of the European wheat yellow rust population by new races from the centre of diversity in the near-Himalayan region. Plant Pathology 65 (3): $402-411$. DOI: 10.1111/ppa.12433.

Johnson R. 1992. Past, present and future opportunities in breeding for disease resistance, with examples from wheat. Euphytica 63 (1-2): 3-22. In: "Breeding for Disease Resistance" Developments in Plant Pathology Volume 1 (R. Johnson, G.J. Jellis, eds.). Springer, Dordrecht, 205 pp. ISBN 978-90-481-4124-1. DOI: https://doi.org/10.1007/978-94-017-0954-5_1.

KOMUGI - Wheat Genetic Resources Database 2016. http://shigen.nig.ac.jp/wheat/komugi/top/top.jsp [Accessed: 15.11.2016].

Li Q., Wang B., Chao K., Guo J., Song J., Yue W., Li Q. 2016. Molecular detection of stripe rust resistance gene(s) in 115 wheat cultivars (lines) from the yellow and huai river valley wheat region. Journal of Phytopathology 164 (11-12): 946-958. DOI: 10.1111/jph.12515.

MASWheat 2016. http://maswheat.ucdavis.edu [Accessed: 22.11.2016].

McNeal F.H., Konzak C.F., Smith E.P., Tate W.S., Russel T.S. 1971. A uniform system for recording and processing cereal research data. United States Department of Aghriculture, Agricultural Research Service, Washington, D.C., ARS 34-121, 42 pp.

Morgounov A., Tufan H.A., Sharma R., Akin B., Bagci A., Braun H.-J., Kaya Y., Keser M., Payne T.S., Sonder K., McIntosh R. 2012. Global incidence of wheat rusts and powdery mildew during 1969-2010 and durability of resistance of winter wheat variety Bezostaya 1. European Journal of Plant Pathology 132 (3): 323-340. DOI: 10.1007/s10658-011-9879-y.

Murphy L.R., Santra D., Kidwell K., Yan G., Chen X., Campbell K.G. 2009. Linkage maps of wheat stripe rust resistance genes Yr5 and Yr15 for use in marker-assisted selection. Crop Science 49 (5): 1786-1790. DOI: 10.2135/cropsci2008.10.0621.

Rampling L.R., Harker N., Shariflou M.R., Morell M.K. 2001. Detection and analysis systems for microsatellite markers in wheat. Australian Journal of Agricultural Research 52 (12): 1131-1141. DOI: https://doi.org/10.1071/AR01027.

Sharma-Poudyal D., Chen X.M., Wan A.M., Zhan G.M., Kang Z.S., Cao S.Q., Jin S.L., Morgounov A., Akin B., Mert Z., Shah S.J.A., Bux H., Ashraf M., Sharma R.C., Madariaga R., Puri K.D., Wellings C., Xi K.Q., Wanyera R., Manninger K., Ganzález M.I., Koyda M., Sanin S., Patzek L.J. 2013. Virulence characterization of international collections of the wheat stripe rust pathogen, Puccinia striiformis f. sp. tritici. Plant Disease 97 (3): 379-386. DOI: https://doi.org/10.1094/PDIS-01-12-0078-RE.

Smith P.H., Hadfield J., Hart N.J., Koebner R.M.D., Boyd L.A. 2007. STS markers for the wheat yellow rust resistance gene Yr5 suggest a NBS-LRR-type resistance gene cluster. Genome 50 (3): 259-265. DOI: https://doi.org/10.1139/G07-004.

Sortinfo 2016. www.sortinfo.dk/Sorter.asp [Accessed: 15.11.2016].

Tratwal A., Gacek E. 2013. Znaczenie odmian odpornych na choroby i zasiewów mieszanych roślin uprawnych. s. 35-44. W: „Podstawy integrowanej ochrony roślin" (M. Mrówczyński, red.). PWRiL, Poznań, 156 ss.

Woźniak-Strzembicka A. 2003. Rdza żółta pszenicy w Polsce: częstość wirulencji w populacji patogena. Biuletyn Instytutu Hodowli i Aklimatyzacji Roślin 230: 119-126.

Yaniv E., Raats D., Ronin Y., Korol A.B., Grama A., Bariana H., Dubcovscy J., Schulman A.H., Fahima T. 2015. Evaluation of marker-assisted selection for the stripe rust resistance gene $\mathrm{Yr} 15$, introgressed from wild emmer wheat. Molecular Breeding 35: 43. DOI: 10.1007/s11032-015-0238-0. 